\title{
ESTIMASI NILAI POROSITAS DAN PERMEABILITAS DENGAN PENDEKATAN DIGITAL ROCK PHYSICS (DRP) PADA SAMPEL BATUPASIR FORMASI NGRAYONG, CEKUNGAN JAWA TIMUR BAGIAN UTARA
}

\author{
Benyamin Elilaski Nababan ${ }^{1, *}$, Eliza Veronica Zanetta ${ }^{2}$, Nahdah Novia $^{3}$, dan Handoyo ${ }^{4}$ \\ 1,2,3,4 Teknik Geofisika Institut Teknologi Sumatera \\ Jalan Terusan Ryacudu, Desa Way Hui, Jati Agung, Lampung Selatan 35365, (0721) \\ 8030188/pusat@itera.ac.id \\ Corresponding author: elilaskinababan@gmail.com \\ Manuscript received: July 3, 2019; revised: August 21, 2019; \\ Approved: August 23, 2019; available online: November 11, 2019
}

\begin{abstract}
Abstrak - Porositas dan permeabilitas batuan reservoir adalah parameter-parameter sifat fisis batuan yang mengontrol kualitas reservoir. Secara konvensional, nilai porositas dan permeabilitas batuan diperoleh dari pengukuran di laboratorium atau melalui data sumur (well log). Saat ini, perhitungan porositas dan permeabilitas dapat dihitung dengan menggunakan pemrosesan gambar digital/Digital Rock Physics (DRP). Sampel data inti diproses dengan difraksi sinar-X menggunakan CT-Scan micro-tomography. Hasilnya adalah model gambar dari sampel inti yaitu gambar 2D dan 3D. Kombinasi pemrosesan teoritis dan citra digital dapat diperoleh nilai porositas dan permeabilitas sampel batuan. Dalam penelitian ini kami menghitung nilai porositas dan permeabilitas menggunakan pendekatan Digital Rock Physics (DRP) pada sampel batupasir Formasi Ngrayong, Cekungan Jawa Timur bagian Utara. Hasil dari simulasi dan pengolahan citra digital pada sampel batupasir Formasi Ngrayong berkisar pada nilai $33.50 \%$ dan permeabilitas sekitar 1267.02 mDarcy.

Abstract - Reservoir rock permeability and porosity are physical properties of rocks that control reservoir quality. Conventionally, rock porosity and permeability values are obtained from measurements in the laboratory or through well logs. At present, calculation of porosity and permeability can be calculated using digital image processing / Digital Rock Physics (DRP). Core data samples are processed by X-ray diffraction using CT-microtomography scan. The result is an image model of the core sample, 2D and 3D images. The combination of theoretical processing and digital images can be obtained from the value of porosity and permeability of rock samples. In this study, we calculated porosity and permeability values using the Digital Rock Physics (DRP) approach in sandstone samples from the Ngrayong Formation, North East Java Basin. The results of the digital image simulation and processing on the Ngrayong Formation sandstone samples ranged in value from $33.50 \%$ and permeability around $1267.02 \mathrm{mDarcy}$.
\end{abstract}

Keywords: CT-Scan, Digital Rock Physics (DRP), Sandstone Ngrayong Formation

How to cite this article:

Nababan, B.E., Zanetta, E.V., Novia, N., dan Handoyo, 2019, Estimasi Nilai Porositas dan Permeabilitas dengan Pendekatan Digital Rock Physics (DRP) Pada Sampel Batupasir Formasi Ngrayong, Cekungan Jawa Timur Bagian Utara, Jurnal Geofisika Eksplorasi, 5 (3) p.193-203. doi: 10.23960/jge.v5i3.34 


\section{PENDAhuluan}

Porositas dan permeabilitas adalah parameter penting dalam batuan reservoir minyak dan gas. Dalam sistem perminyakan, batuan reservoir adalah batuan sedimen yang mampu menahan/ membawa cairan (minyak, gas, dan air) dalam jumlah tertenu. Kualitas reservoir yang baik ditentukan oleh nilai porositas yang baik ditentukan oleh nilai porositas dan permeabilitas yang tinggi. Oleh karena itu, perlu untuk mengukur nilai porositas dan permeabilitas batuan. Dalam pengukuran tambahan di laboratorium (konvensional), metode digital kini telah dikembangkan untuk mengukur nilai porositas dan permeabilitas (Andrä, 2013).

Metode DRP adalah metode yang memanfaatkan fungsi CT-Scan untuk mengidentifikasi geometri pori-pori batuan, retakan, dan memprediksi nilai porositas dan permeabilitas batuan (Fourier, 2014). Hasil gambar digital dari metode DRP adalah visualisasi gambar dalam $2 D$ dan $3 D$. Metode ini juga dapat memberikan perkiraan waktu yang lebih cepat dan efektif serta menentukan parameter fisik batuan secara lebih rinci. Maka penelitian ini diharapkan dapat membantu para ahli terutama bidang geologi (petrofisika) dan geofisika untuk meneliti lebih detail parameter fisik batuan. Perhitungan parameter fisik batuan menggunakan metode DRP dapat diterapkan menggunakan simulasi komputer/digital. Pada penelitian sebelumnya (Handoyo dkk, 2014), aplikasi Digital Rock Physics (DRP) telah dilakukan tidak hanya untuk menghitung porositas dan permeabilitas, melainkan telah diaplikasikan pula untuk memprediksi nilai parameter elastisitas batuan dan pengaruh keberadaan fluida terhadap sifat fisis batuan.

Penelitian ini bertujuan untuk mengaplikasi metode fisika batuan digital $(D R P)$ untuk memvisualisasikan gambar batuan $2 D$ dan $3 D$ serta memprediksi nilai porositas dan permeabilitas pada sampel batupasir Formasi Ngrayong.

\section{TINJAUAN PUSTAKA}

\subsection{Teoritis}

Sampel batuan umumnya terdiri dari dua bagian utama: pori-pori dan matriks batuan padat (Gambar 1). Kuantitas pori batuan dinyatakan oleh nilai porositas. Porositas $(\varnothing)$ adalah rasio antara volume pori (Vpori) dari total volume batuan (Vtotal) yang secara matematis ditulis sebagai berikut (Mavko dkk, 2009):

$$
\varnothing=\frac{V_{\text {pore }}}{V_{\text {total }}}=1-\frac{V_{\text {matriks }}}{V_{\text {total }}}
$$

Selanjutnya Kozeny Carman memberikan hubungan antara porositas, permeabilitas, permukaan internal spesifik dan turtuositas sebagai (Dvorkin, 2009),

$$
k_{\text {absolute }}=\frac{1}{2} \frac{\phi^{3}}{s^{2} \tau^{2}}
$$

Dengan $\varnothing$ adalah nilai porositas, $S$ adalah luas permukaan internal spesifik dan $\tau$ adalah turtuositas.

Pendekatan dengan metode DRP merupakan pendekatan alternatif untuk menyelesaikan secara komputasi nilai porositas dan permeabilitas langsung pada model mikro digital (Roberts dan Garboczi, 2000). Memori komputer dan kecepatan pemrosesan data memungkinkan untuk menangani model 3D besar dan jumlah perhitungan yang dibutuhkan untuk mendapatkan hasil yang bermanfaat.

\subsection{Geologi Regional}

Secara umum daerah Cepu dan sekitarnya terletak di Zona Rembang, Cekungan Jawa Timur bagian Utara (Van Bemmelen, 1949). Pada Zaman Paleogen Cekungan Jawa Timur bagian Utara telah mengalami regim tektonik regangan yang merupakan akibat dari gerakan mundur (roll back) kearah selatan dari jalur magmatik yang ada pada zaman kapur akhir. Busur magmatik berarah barat dayatimur laut menempati posisi di Pulau Karimunjawa dan Pulau Bawean. Busur magmatik tersebut menjadi arah barat timur 
pada posisi di pantai selatan Jawa Timur. Sedangkan pada Zaman Neogen posisi busur magmatik berada pada daerah sebelah utara Kabupaten Pacitan-Trenggalek dan menerus ke timur, dengan arah busur magmatik tetap barat-timur. Perubahan gerakan maju dari busur magmatik Zaman Neogen ini menyebabkan terjadinya regim tektonik kompresi yang menghasilkan struktur geologi lipatan dan sesar di daerah Cekungan Jawa Timur bagian Utara, dimana kedua faktor tersebut merupakan faktor utama didalam pembentukan sistem petroleum (Gambar 2).

Stratigrafi daerah ini termasuk ke dalam stratigrafi mandala rembang (Harsono, 1983), tersusun oleh formasi batuan dari tua ke muda berturut-turut adalah Formasi Kujang, Formasi Prupuh, Formasi Tuban, Formasi Ledok, Formasi Mundu, Formasi Selorejo, Formasi Lidah dan endapan yang termuda disebut endapan Undak Solo dengan tebal total cekungan sedimentasi lebih dari 3000 meter (Gambar $3)$.

Lokasi pengambilan sampel batupasir adalah singkapan yang berasal dari Formasi Ngrayong yang merupakan salah satu reservoir minyak bumi di Blok Cepu (Gambar 4).

\subsection{Data Laboratorium Petrofisika}

Pada hasil uji laboratorium petrofisika yang telah dilakukan pada sampel batuan yang sama pada penelitian ini, menunjukkan nilai porositas berkisar $33.24 \%$, dan permeabilitas berkisar 1150 mDarcy.

\section{METODE PENELITIAN}

Adapun metodologi pengerjaan pada penelitian ini yaitu:

\subsection{Akuisisi data}

Akuisisi data dalam hal ini pengambilan sampel data core batupasir dilakukan dipermukaan pada singkapan batupasir Formasi Ngrayong. Kemudian dilakukan perekaman menggunakan $C T$ -
Scan SKYSCAN 1173 dengan perekaman resolusi tinggi-tunggal (scan high resolution-single). Hasil perekaman menghasilkan lebih dari 1000 gambar $2 D$ slice batuan. Kemudian irisan $2 D$ batuan tersebut direkonstruksi untuk meningkatkan kualitas citra gambarnya menggunakan perangkat lunak NRecon (Bruker Micro$C T$ ) dan GPUReconServer untuk mempercepat rekonstruksi inti (Gambar 5).

\subsection{Pemrosesan data}

Pemrosesan data citra digital menggunakan perangkat lunak Fiji. Perangkat lunak ini dapat digunakan untuk menentukan model $2 D$ dan $3 D$ dari data hasil scanning. Kemudian nilai porositas dan permeabilitas akan dihitung menggunakan kombinasi antara hasil komputasi dan perangkat lunak Fiji dan perhitungan manual menggunakan Microsoft excel atau Matlab (Gambar 6).

\subsection{Interpretasi dan analisis}

Adapun tahapan interpretasi dan analisis data yang dilakukan ditunjukkan pada gambar 7. Pada tahapan ini nilai porositas dan permeabilitas yang didapat dihubungkan dengan klasifikasi nilai porositas menurut (Harsono, 1997) pada tabel 2, dan klasifikasi permeabilitas menurut (Koesoemadinata, 1978) pada tabel 3 .

\section{HASIL DAN PEMBAHASAN}

\subsection{Hasil}

Pada penelitian ini menggunakan sampel data inti/core singkapan batupasir dengan ukuran 3x4.5cm (Gambar 8a) yang direkam mengunakan CT-Scan dengan perekaman resolusi tinggi-tunggal. Hasil perekaman menghasilkan citra digital sampel batuan secara 3D (Gambar 8b). perlu dilakukan rekonstruksi untuk meghilangkan efek-efek bising/noise yang ikut terekam pada saat proses scanning berlangsung. Rekonstruksi ini menghasilkan citra gambar 2D (Gambar 9). 
Pada pemrosesan data, hasil rekonstruksi (reconstruction image) digunakan sebagai data inputan untuk pemilihan ROI (Region of Interest) dengan ukuran 400x400x400 pixel. Pemilihan ROI ini dilakukan untuk menentukan wilayah ideal pada slice gambar hasil perekaman untuk dijadikan bentuk $3 D$ (Gambar 10). Kemudian dilakukan proses thresholding untuk membedakan antara pori dan matriks pada sampel batuan (Gambar 11). Proses tresholding masih memiliki noise yang dicirikan dengan adanya bintik atau pepper. Hal ini perlu dilakukan filtering (despackle) (Gambar 12).

Pada penelitian ini visualisasi secara $3 D$ berjumlah 16 bagian kubus dapat mewakili hasil perekaman seluruhnya pada sampel batupasir Formasi Ngrayong (Gambar 13). Dengan memasukkan perhitungan matematis dari hasil pemrosesan data tersebut, dihasilkan nilai perhitungan porositas dan permeabilitas (Tabel 1).

Dengan menggunakan metode DRP pada sampel menunjukkan nilai porositas sebesar $33.50 \%$ dan nilai permeabilitas sebesar 1267.02 mDarcy. Hasil yang didapat pada penelitian ini tidak jauh berbeda dengan nilai yang didapat pada data hasil uji laboratorium petrofisika yang sudah dilakukan pada sampel yang sama.

Dari hasil visualisasi 2D dan 3D dengan metode DRP ini menunjukkan hasil bahwa sampel batuan termasuk kategori batupasir berporos dan memiliki kemampuan meloloskan fluida dimana antar matriks memiliki hubungan yang sangat baik sehingga memungkinkan batuan ini memiliki kemampuan yang baik untuk mengakumulasikan fluida seperti minyak bumi, gas, dan air (Gambar 14).

\subsection{Pembahasan}

Pada penelitian ini kita mengasumsikan bahwa dengan ukuran citra gambar 2D 400 x 400 x 400 pixel sebanyak 16 bagian dapat memberikan hasil yang lebih baik dan akurat dalam perhitungan nilai porositas dan permeabilitas. Hal ini membuat semua hasil perekaman dapat terpakai seutuhnya dan memperkecil nilai error yang didapatkan. Hal lain yang juga harus diperhatikan yaitu perlu adanya ketelitian dalam proses filtering. Proses ini harus dilakukan secara teliti karena dapat mengakibatkan informasi pori yang ingin didapat justru dikategorikan sebagai noise.

Rekonstruksi citra digital telah dilakukan untuk memodelkan bentuk digital batuan. Dalam beberapa kasus perlu dilakukan interpretasi untuk menentukan sebesar apa perlunya filtering pada citra digital, dengan harapan tidak terjadi perbedaan yang signifikan antara real data dan hasil modeling.

\section{KESIMPULAN}

\subsection{Kesimpulan}

Adapun kesimpulan dari penelitian ini adalah sebagai berikut:

1. Penelitian ini menghasilkan citra batuan secara $2 D$ dan $3 D$ dengan menggunakan pendekatan Digital Rock Physics (DRP).

2. Hasil perhitungan menunjukkan bahwa nilai rata-rata porositas sampel batupasir Formasi Ngrayong yaitu $33.50 \%$ dan nilai rata-rata permeabilitasnya sebesar 1267.02 mDarcy.

3. Nilai porositas dan permeabilitas yang tinggi diinterpretasikan sebagai lapisan batupasir yang ideal sebagai batuan reservoir minyak/gas bumi.

\section{UCAPAN TERIMA KASIH}

Terimakasih kepada Dr. Fourier Dzar Eljabbar Latief S.Si., M.Si. selaku penanggung jawab operasional $\mu C T$ di laboratorium Micro-CT Scan Fakultas Matematika dan Ilmu Pengetahuan Alam Institut Teknologi Bandung yang sudah memberikan pengetahuan mengenai instrumen $\quad \mu C T$. Serta kepada 
Kemenristekdikti sebagai pihak pendanaan pada penelitian ini.

\section{DAFTAR PUSTAKA}

Andrä, H., Combaret, N., Dvorkin, J., Glatt, E., Han, J., Kabel, M., Keehm, Y., Krzikalla, F., 376 Lee, M., Madonna, C., Marsh, M., Mukerji, T., Saenger, E.H., Sain, R., Saxena, N., Ricker, 377 S., Wiegmann, A., Zhan, X., 2013, a Digital rock physics benchmarks-Part I: imaging and 378 segmentation. Comp. Geosci. 50, 25-32, USA.

Bemmelen, R.W.an., 1949. The Geology of Indonesia, Vol. IA, Netherland.

Dvorkin, J., Nur, A., and Yin, H., 1994, Effective Properties of Cemented Granular Materials, Mechanics of Materials, 18, 351-366. Dvorkin, J., and Nur, A., 1996, Elasticity of high porosity Sandstones: Theory for Two North Sea Datasets, Geophysics, 61, 1363-1370, Stanford University, UK.

Fourier, D.E.L., 2014. Analysis of Permeability and Tortuosity of Fontainebleau Sandstone and its Models Using Digital Rock Physics Approach. Physics of Earth and Complex System, Faculty of Mathematics and Natural Sciences, Bandung Institute of Technology, Indonesia.

Hampson, D. dan Russel, B., 2011, AVO: Workshop Part-1. Hampson-Russel Software Service,Ltd.

Han, D., 1986, Effects of porosity and clay content on acoustic properties of sandstones and unconsolidated sediments: Ph.D. dissertation, Stanford University, UK.

Handoyo., Fatkhan., Fourier, D.E.L., 2014, Digital Rock Physics Application:
Structure Parameters Characterization, Materials Identification, Fluid Modeling, and Elastic Properties Estimation of Saturated Sandstones, HAGI Proceeding 2014 Solo, Bandung Institute of Technology, Indonesia.

Harsono, P., 1983, Biostratigrafi North East Java Basin. Disertasi Doktor, Bandung.

Kusumadinata, R.P., 1978, Geologi Minyak dan Gas Bumi, Penerbit ITB, Bandung.

Mavko, G., and Nur, A., 2009, The Rock Physics Handbook, Second Edition Tools for Seismic Analysis of Porous Media. Cambridge University Press The Edinburgh Building, Cambridge CB2 8RU, UK.

Pringgoprawiro, H., 1985, Stratigrafi Cekungan Jawa Timur Utara dan Paleogeografinya: sebuah pendekatan baru, Disertasi Doktor, ITB, Indonesia.

Roberts, A. P., and Garboczi, E. J., 2000, Elastic properties of model porous ceramics: J. Amer. Ceramic Soc., 83, 3041-3048, USA. 
Tabel 1. Hasil perhitungan porositas dan permeabilitas

\begin{tabular}{ccc}
\hline Kode & Porositas (\%) & Permeabilitas (mD) \\
\hline BN_01 & 38.0794875 & 1780.828368 \\
BN_02 & 36.2083525 & 1483.924711 \\
BN_03 & 35.4249125 & 1382.471231 \\
BN_04 & 32.28858 & 1074.539317 \\
BN_05 & 34.04271 & 1256.757389 \\
BN_06 & 33.7249375 & 1191.067531 \\
BN_07 & 33.9025525 & 1199.737513 \\
BN_08 & 33.3581925 & 1128.450217 \\
BN_09 & 29.8252875 & 792.5502371 \\
BN_10 & 25.738185 & 506.2111719 \\
BN_11 & 29.41742 & 762.0049035 \\
BN_12 & 34.0697675 & 1201.188063 \\
BN_13 & 33.0790125 & 1194.296824 \\
BN_14 & 33.030345 & 1392.949804 \\
BN_15 & 35.8992375 & 1751.734984 \\
BN_16 & 37.9416425 & 2173.751161 \\
\hline Ratarata & 33.50191391 & 1267.028964 \\
\hline
\end{tabular}

Tabel 2. Klasifikasi nilai porositas (Harsono, 1997)

\begin{tabular}{cc}
\hline Porositas (\%) & Klasifikasi \\
\hline $0-5$ & Dapat diabaikan (negliegible) \\
$5-10$ & Buruk (poor) \\
$10-15$ & Cukup (fair) \\
$15-20$ & Baik (good) \\
$20-25$ & Sangat baik (very good) \\
$<75$ & Istimewa (excellent) \\
\hline
\end{tabular}

Tabel 3. Klasifikasi permeabilitas (Koesoemadinata, 1978)

\begin{tabular}{cc}
\hline Kualitas & $\begin{array}{c}\text { Nilai Permeabilitas } \\
(\mathbf{m D a r c y})\end{array}$ \\
\hline Sangat buruk & $<1$ \\
Buruk & $1-50$ \\
Sedang & $50-200$ \\
Baik & $200-500$ \\
Sangat baik & $>500$
\end{tabular}




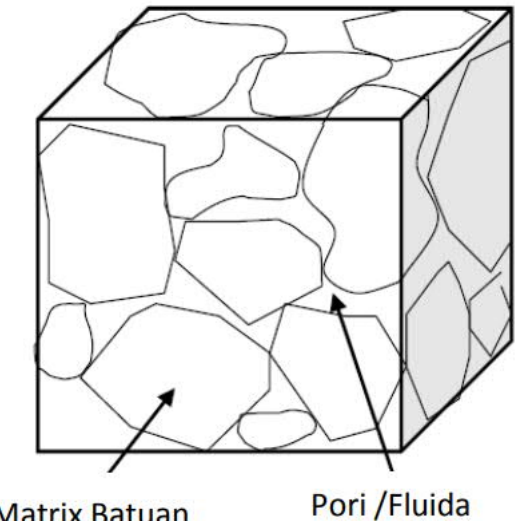

Gambar 1. Model batuan (Humpson - Russel, 2011)

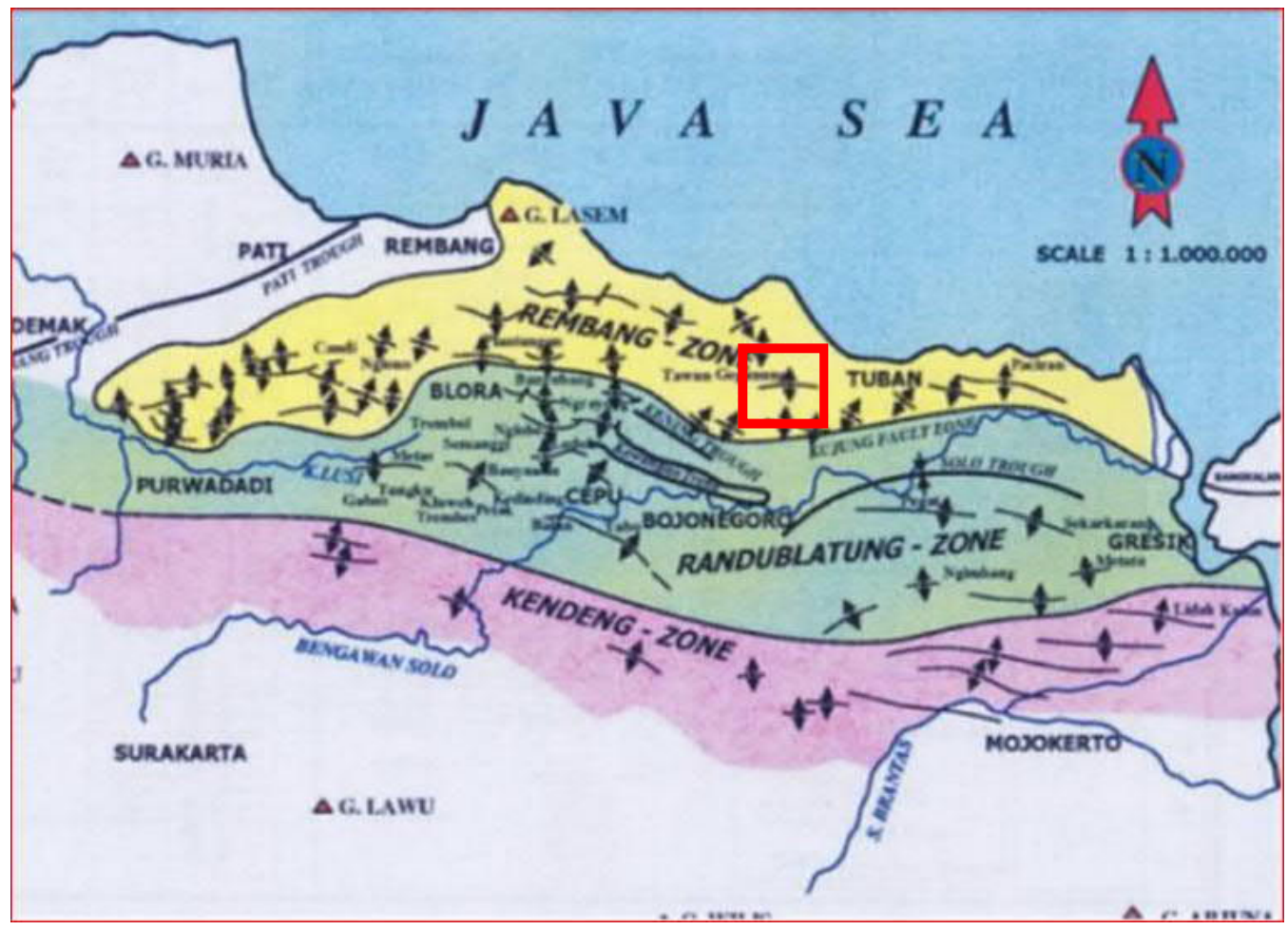

Gambar 2. Peta lokasi geologi regional Blok Cepu (Van Bemmelen, 1949) 


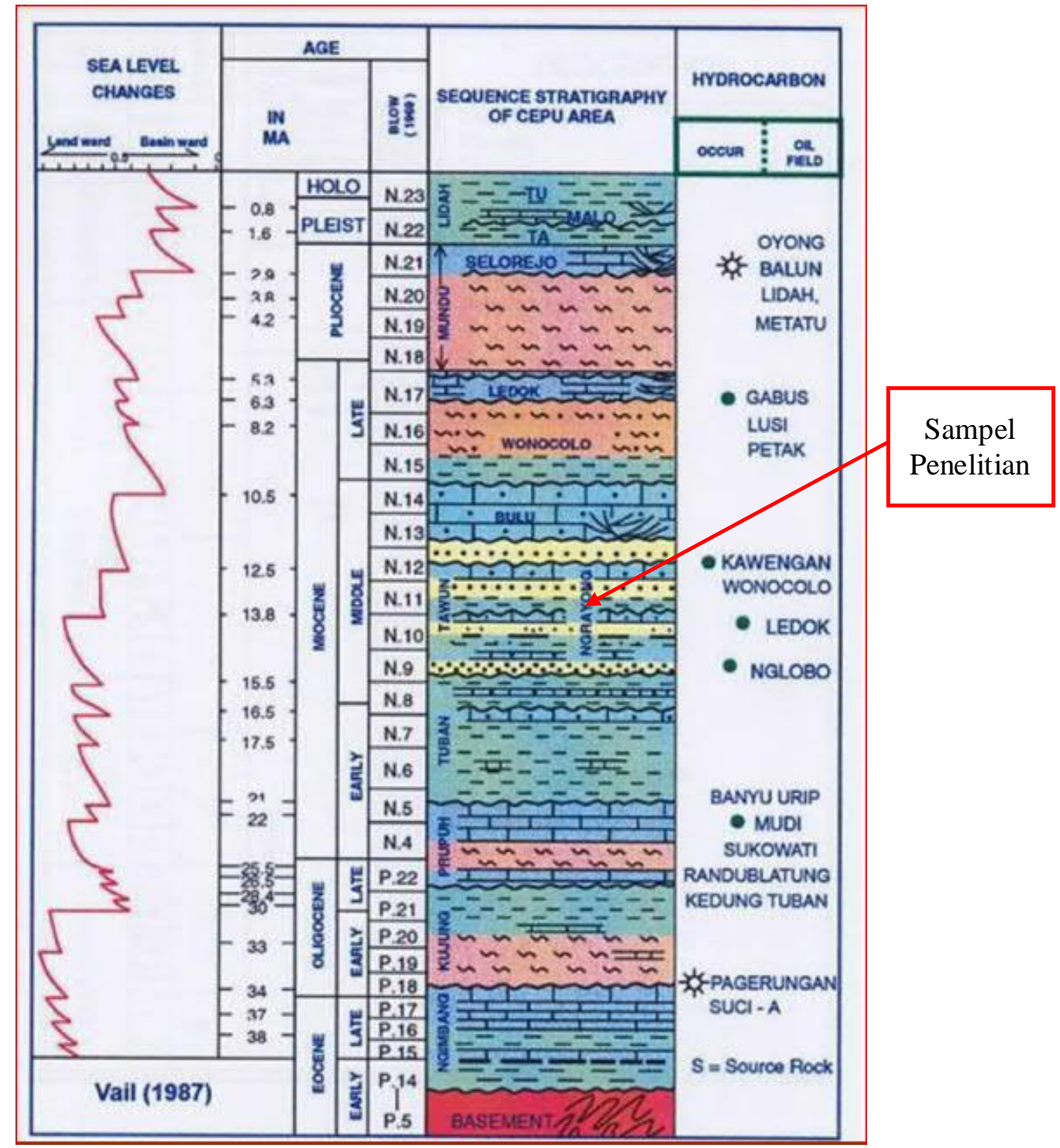

Gambar 3. Stratigrafi Blok Cepu, Mandala Rembang (Harsono, 1985)
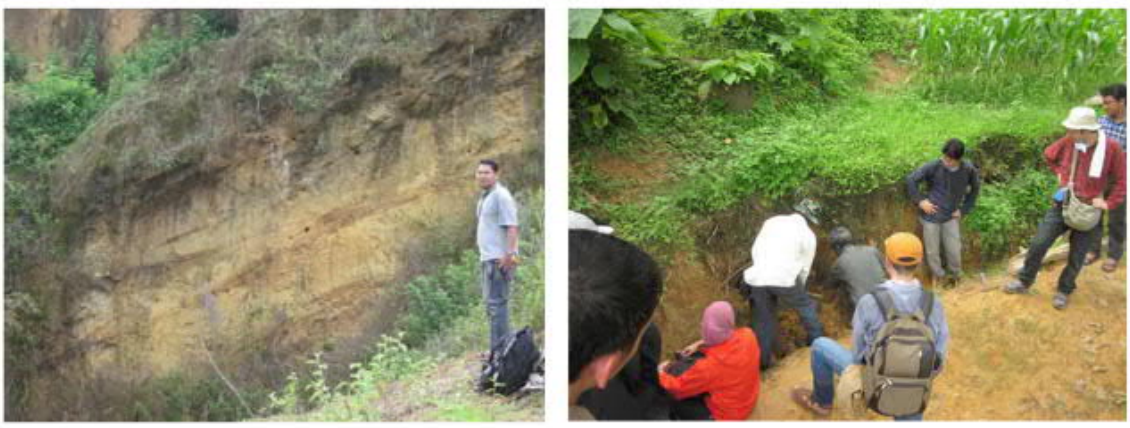

Gambar 4. Singkapan batupasir Formasi Ngrayong 


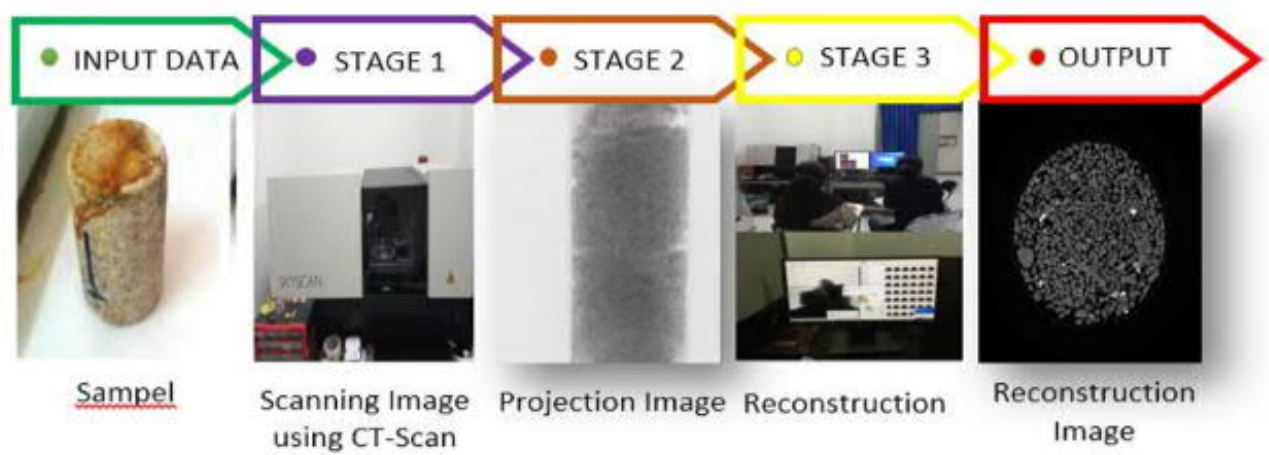

Gambar 5. Diagram alir akuisisi data

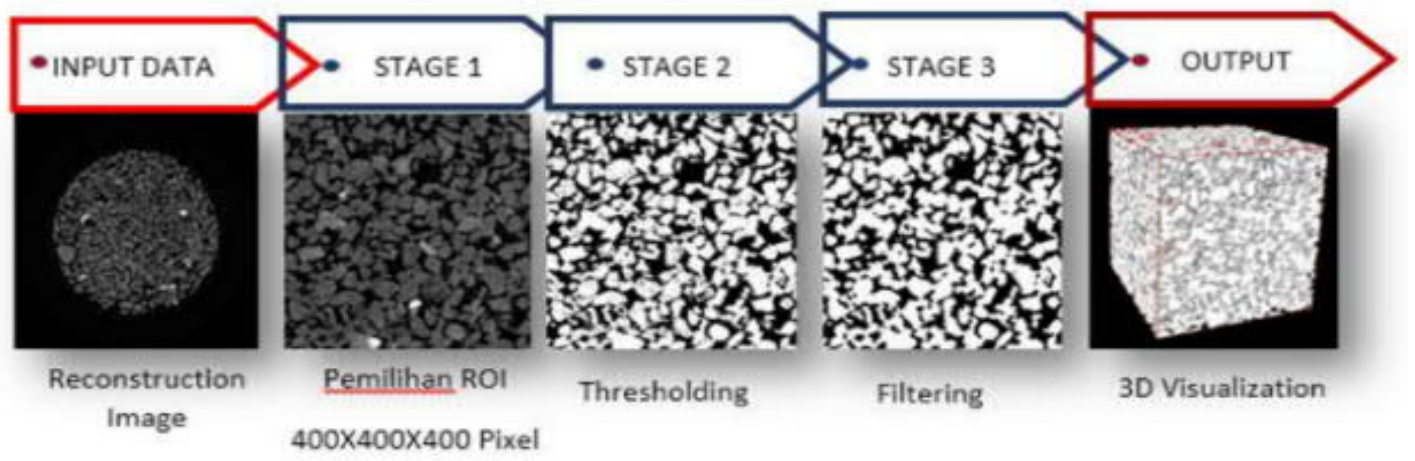

Gambar 6. Diagram alir pemrosesan data

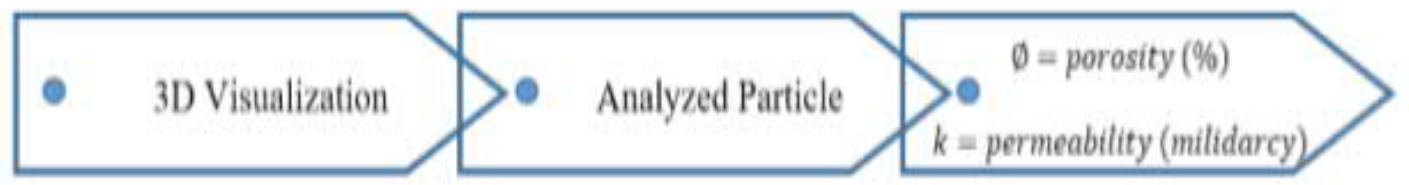

Gambar 7. Diagram alir analisis data
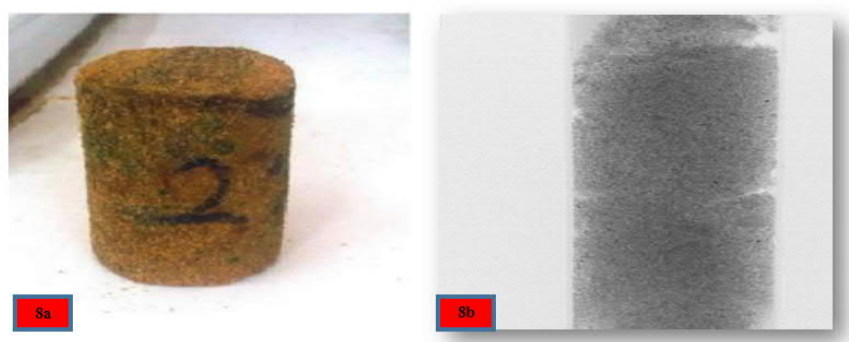

Gambar 8. Sampel core batupasir (8a), dan proyeksi gambar 3D perekaman CT-Scan (8b) 


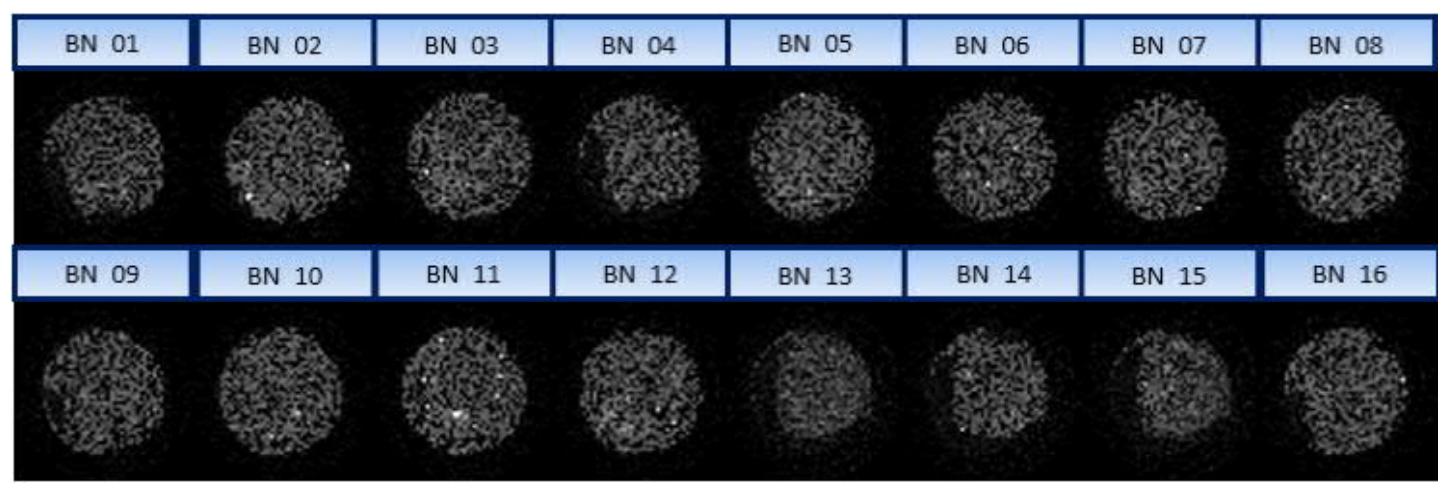

Gambar 9. Hasil rekonstruksi gambar 2D

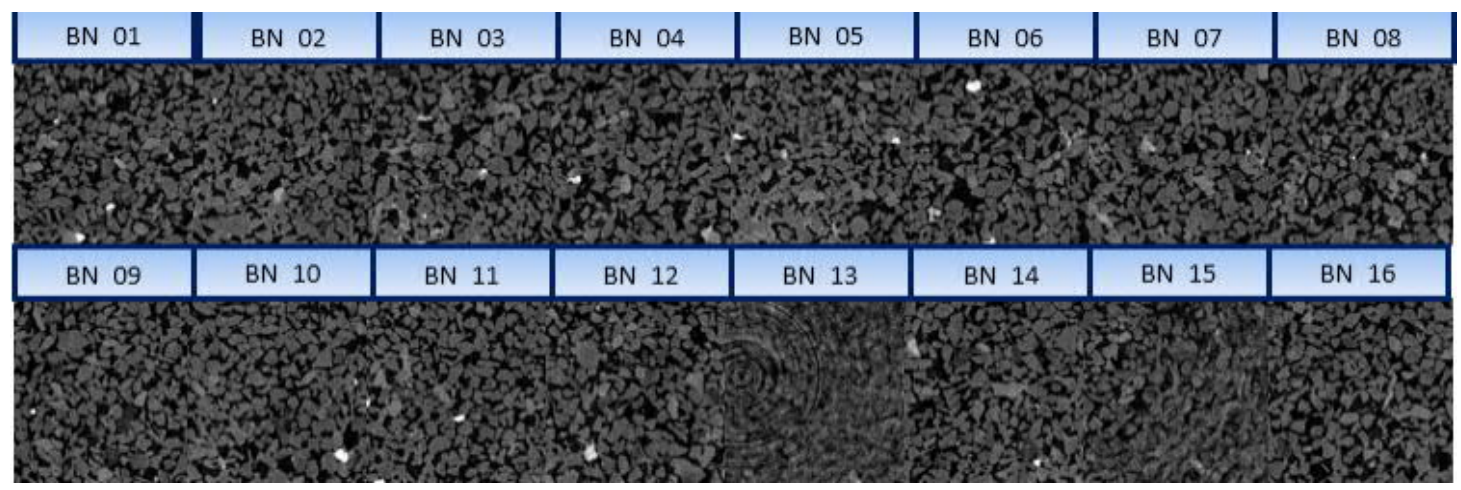

Gambar 10. Hasil pemilihan ROI (Region of Interest)

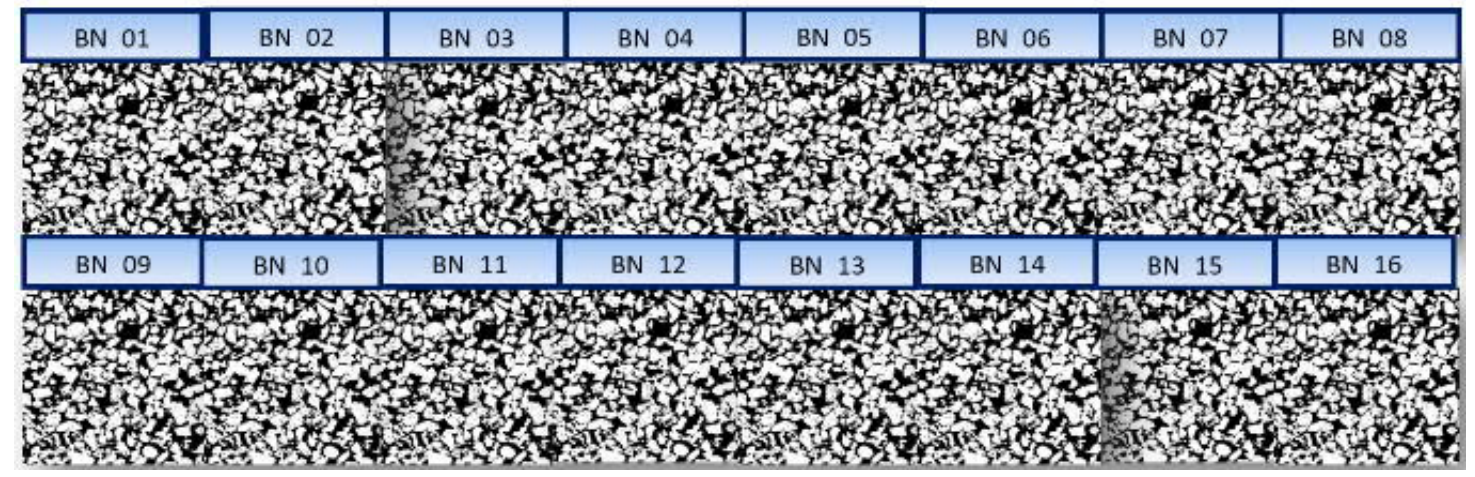

Gambar 11. Thresholding

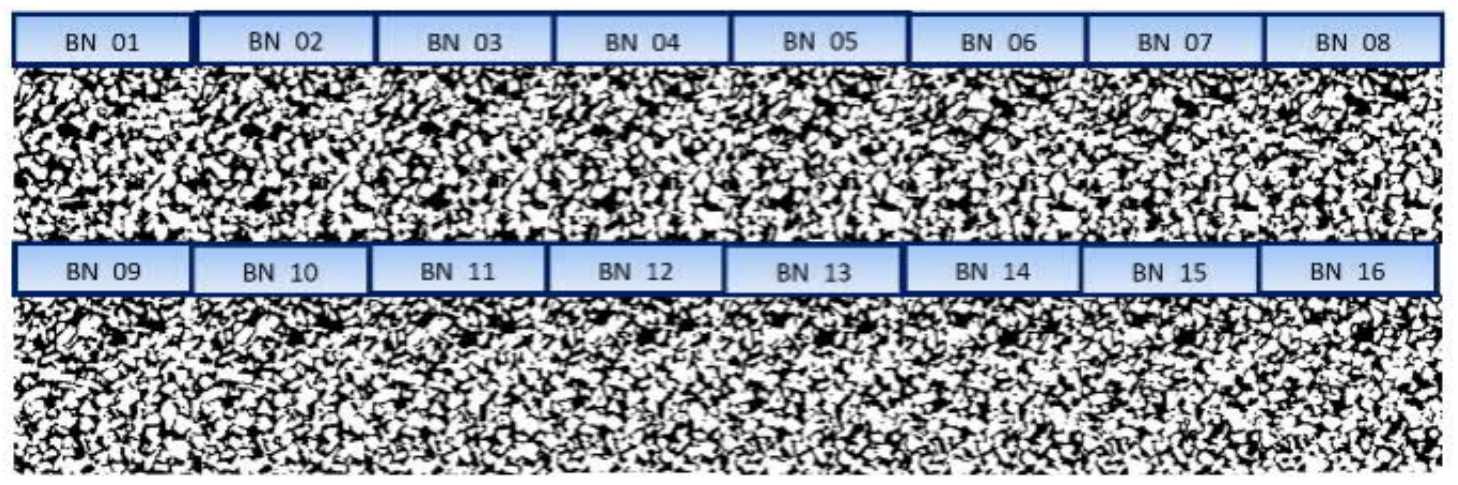

Gambar 12. Filtering 


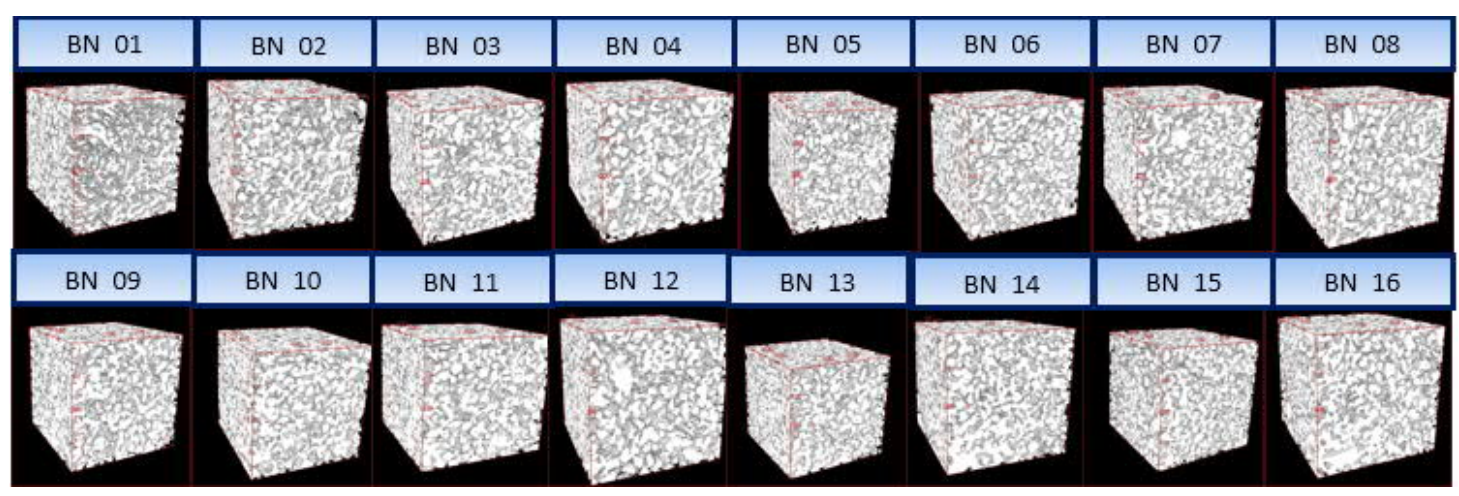

Gambar 13. Hasil Visualisasi 3D

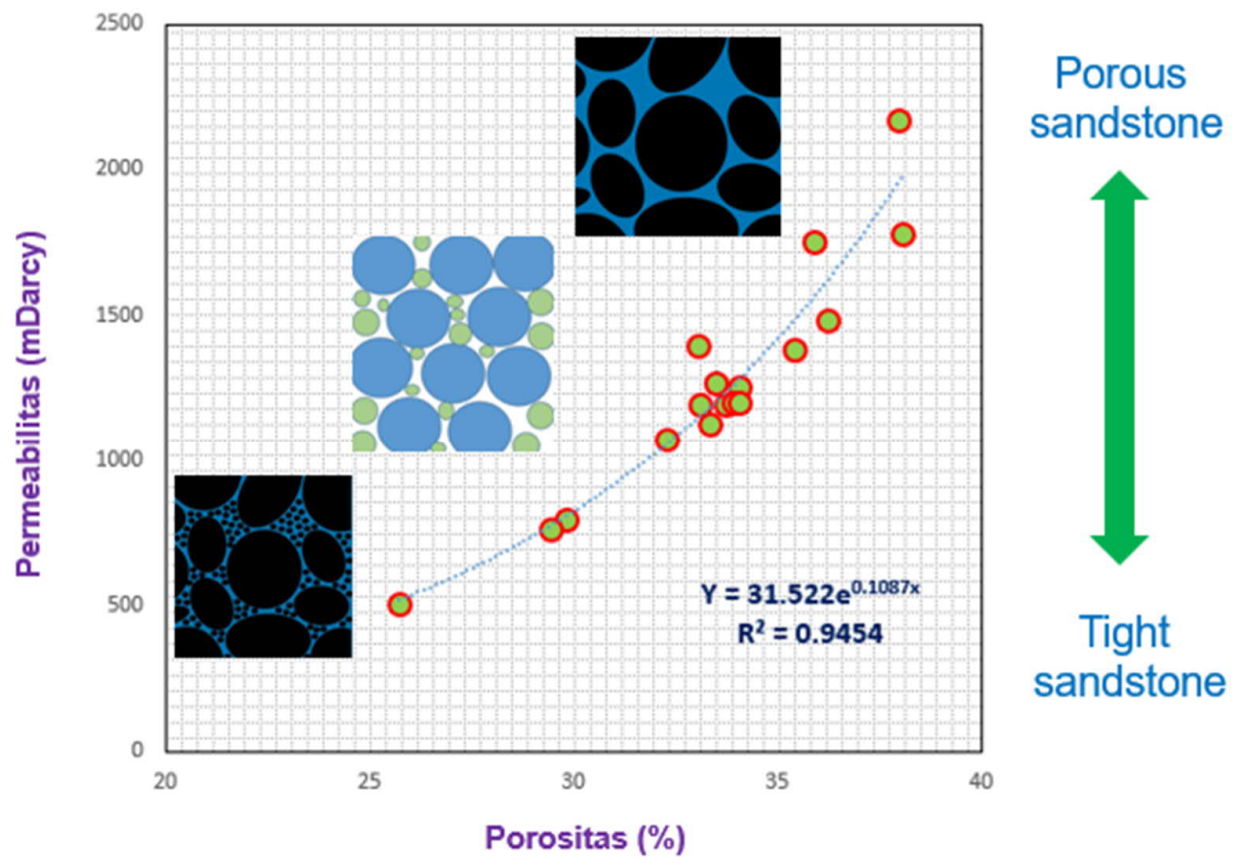

Gambar 14. Grafik hubungan antara porositas dan permeabilitas 